\title{
DIGITÁLIS TARTALMAK KÖNYVTÁRI FELHASZNÁLÁSA A CSELEKVŐ KÖZÖSSÉGEK WIKI FEJLESZTÉSE AZ ORSZÁGOS SZÉCHÉNYI KÖNYVTÁRBAN
}

\author{
Nagy Andor \\ Országos Széchényi Könyvtár \\ nagy.andor@oszk.hu \\ ORCID: 0000-0002-9404-0091
}

DOI: 10.31915/NWS.2018.12

Use of digital content in libraries: Development of the Acting Communities in the National Széchényi Library This article presents a possible way to re-use a digital content through the process of develop Acting Communities Wiki which is the first community encyclopedia about community and their development. The article focuses on accessibility of web interfaces and provides a good example for libraries how to creatively reuse a digital content.

Keywords: community projects, wikis, web content

\section{Bevezetés}

2016-ban elindult a „Cselekvő közösségek - aktív közösségi szerepvállalás” EFOP-1.3.1-15-201600001 kódszámú projekt', amely egy háromtagú konzorcium közreműködésével valósul meg 2019 szeptemberéig. A konzorciumvezető a Szabadtéri Néprajzi Múzeum², a két másik tagja pedig az NMI Müvelődési Intézet Nonprofit Közhasznú Kft. ${ }^{3}$ és az Országos Széchényi Könyvtár (OSZK)4. A projekt költségvetése 3.000.000.000 Ft, időtartama pedig 36 hónap. Elsődleges célja, hogy képessé tegye az önkormányzatokat, regionális szintü közösségi szervezeteket és a kulturális intézményeket a közösségi kezdeményezések befogadására, támogatására és az elért eredmények megtartására. Ezek elérése érdekében kutatásokat folytat, hazai és nemzetközi gyakorlatokra alapozott módszertanokat és kulturális közösségfejlesztő modelleket dolgoz ki. Továbbá mintaprojekteket hoz létre, képzéseket és konferenciákat szervez, kulturális közösségfejlesztő mentorhálózatot üzemeltet, kiadványokat jelentet meg; mindezzel pedig ahhoz járul hozzá, hogy - ahogy a projekt neve is utal rá - valóban müködő, cselekvő közösségeket hozzon létre.

A projekt keretében létrehoztuk Magyarország első olyan wikijét, vagy ha úgy tetszik, közösségi enciklopédiáját, amely a közösségekkel és azok fejlesztésével foglalkozik. A fejlesztést én koordináltam, illetve a tartalomelőállításnak is én vagyok a felelőse. A Cselekvő közösségek wiki szócikkbázisának alapját elsősorban a projekt módszertani kiadványai adják. A portál abban különbözik egy egyszerü online enciklopédiától, hogy wiki-szerü felépítése lehetővé teszi, hogy a tartalomfejlesztésben ne csak a munkatársaink vegyenek részt, hanem egy egyszerü regisztrációt követően bárki szabadon létrehozhasson új szócikkeket vagy akár a meglévőket is szerkeszthesse.

Cselekvő közösségek projekt. „Főoldal”, hozzáférés: 2018. 10. 10, https://cselekvokozossegek.hu

Szabadtéri Néprajzi Múzeum. „Főoldal”, hozzáférés: 2018. 10. 10, http://skanzen.hu

NMI Müvelődési Intézet Nonprofit Közhasznú Kft. „Főoldal”, hozzáférés: 2018. 10. 10, https://kozossegimuvelodes.hu

Országos Széchényi Könyvtár. „Főoldal”, hozzáférés: 2018. 10. 10, http://www.oszk.hu

Cselekvő Közösségek Wiki. „Főoldal”, hozzáférés: 2018. 10. 10, https://cskwiki.hu 


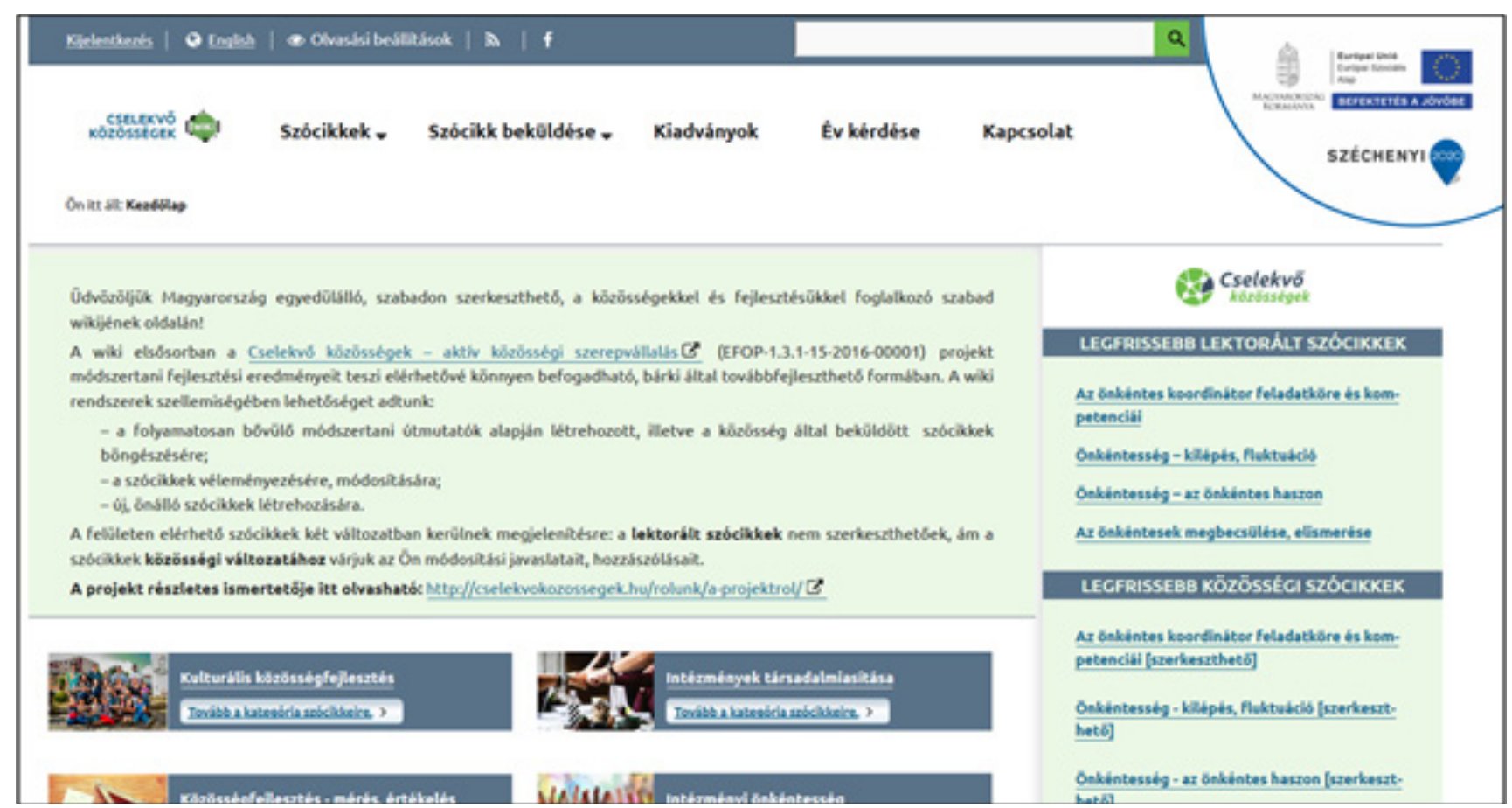

1. ábra a Cselekvő közösségek wiki föoldalának egy része

Hasonlóan müködik tehát, mint a széles körben elterjedt Wikipédia ${ }^{6}$, ám teljesen egyedi megoldásokat is alkalmaztunk. A projekt Megvalósíthatósági Tanulmánya egy „,wiki-szerü rendszer” létrehozását tűzte ki célul, azt nem definiálta, hogy pontosan hogyan nézzen ki az oldal, milyen alapokra épüljön. Így tehát szabad kezet kaptunk a közbeszerzési eljárás kiírásánál, és végül arra jutottunk, hogy a WordPress nevű webes tartalomkezelö-rendszerre épülő wikit szeretnénk létrehozni.

Azért tettük le a voksunkat a WordPress mellett, mert több ezer önkéntes fejlesztő áll mögötte, rendkívül széles körben elterjedt (egyes becslések szerint a weboldalak több mint 30\%-a WordPressre épül ${ }^{8}$ ), és emiatt nagyon jó támogatással rendelkezik, nem utolsó sorban pedig biztonságos. Ezen felül szempont volt még, hogy a WordPress híresen jól testreszabható, ez köszönhető a jól megírt, strukturált kódjának és persze annak, hogy ingyenes, nyílt forráskódú szoftverről van szó.

A nyertes pályázó örömmel vállalta el a Cselekvő közösségek wiki létrehozását, a fejlesztés viszonylag gördülékenyen is haladt, de nehezítette, hogy egy teljesen akadálymentes weboldalt szerettünk volna létrehozni, amely nemcsak a minimálisan elvárt alapszintü akadálymentesítési kritériumoknak tesz eleget, hanem a WCAG 2.0 akadálymentesítési útmutató ${ }^{9}$ emelt szintű (,AA”) akadálymentességet leíró iránymutatásának is.

\footnotetext{
6 Wikipedia. „Főoldal”, hozzáférés: 2018. 10.10, https://www.wikipedia.org

$7 \quad$ WordPress. „Föoldal”, hozzáférés: 2018. 10.10, https://hu.wordpress.org

8 W3Tech Web Technology Survery. „Usage statistics and market share of WordPress for websites”, hozzáférés: 2018. 10. 10, https://w3techs.com/technologies/details/cm-wordpress/all/all

9 World Wide Web Consortium. „Web Akadálymentesítési Útmutató 2.0”, hozzáférés: 2018. 10. 10, http://www.w3c.hu/forditasok/WCAG20
} 


\section{Az akadálymentességröl}

A Központi Statisztikai Hivatal adatai alapján 2011-ben 490578 ember élt valamilyen testi vagy szellemi fogyatékossággal Magyarországon. ${ }^{10}$ Ez a teljes népesség (2011-ben 9985722 fö) ${ }^{11}$ körülbelül 4,9 százaléka, tehát láthatjuk, hogy a társadalom egy jelentős része érintett. Emellett nem mehetünk el szó nélkül, sőt, törekednünk kell arra, hogy egyenlő eséllyel élhessék a mindennapjaikat. Amikor akadálymentesítünk egy épületet vagy elektronikus szolgáltatást, akkor nemcsak a fogyatékkal élök helyzetét könnyítjük meg, hanem azokét is, akiknek képességei csak átmenetileg változtak meg (pl. betegség vagy baleset következtében). Így az említett 4,9 százaléknál valójában sokkal több ember életét könnyítjük meg az akadálymentesítéssel.

A fizikai akadálymentesítés lehetőségeiröl a legtöbb embernek vannak elképzelései, hiszen a jogszabályok világosan leírják, hogy az akadálymentességnek miképpen kell megvalósulnia, a rámpák, liftek, mozgáskorlátozottaknak fenntartott parkolók és a Braille-írással' ${ }^{12}$ készült feliratok mindenki számára láthatók és egyértelmű a funkciójuk.

Ezzel szemben a webes felületek akadálymentességének kérdésköre jóval ingoványosabb terület.

A WCAG 2.0 (Web Content Accessibility Guidelines 2.0) útmutató határozza meg, hogyan lehet a webes tartalmakat könnyen befogadhatóvá, értelmezhetővé tenni a hátrányos helyzetű internethasználók számára. Ez nagyon sok embert érint, pl. a hallási, látási, testi, kognitív, neurológiai vagy más problémával élőket, illetve a megváltozott képességekkel rendelkező idős embereket is. Egy akadálymentesített weboldal természetesen az átlagos felhasználóknak is kedvez, hiszen ezek a weboldalak minden esetben átgondoltan vannak felépítve és első pillantásra is könnyen átláthatók.

Az ajánlást a World Wide Web Konzorcium (W3C)13 dolgozta ki, az első változatát még 1999-ben.

A W3C egy nemzetközi szervezet, elsődleges feladata a web fejlődését segítő szabványok kidolgozása. A szervezetnek vannak föállású munkatársai, de a fejlesztési folyamatokba az internetes közönség is bekapcsolódik, és közel 400 tagszervezettel ${ }^{14}$ müködik együtt. A W3C munkáját a francia székhelyű

10 Tausz Katalin, Phd et al. 2011. évi népszámlálás: 17. A fogyatékossággal élők helyzete és szociális ellátásuk. Budapest: Központi Statisztikai Hivatal, 2015., hozzáférés: 2018. 10.10, http://www.ksh.hu/docs/hun/xftp/idoszaki/nepsz2011/nepsz_17_2011.pdf

11 Központi Statisztikai Hivatal. „Magyarország népességének száma nemek és életkor szerint, január 1.”, hozzáférés: 2018. 10. 10, https:/www.ksh.hu/interaktiv/korfak/orszag.html

12 Magyar Vakok és Gyengénlátók Országos Szövetsége. „,Braille-írás”, hozzáférés: 2018. 10. 10, http://www.mvgyosz.hu/braille-iras

13 World Wide Web Consortium. „A W3C bemutatása”, hozzáférés: 2018. 10. 10, http://www.w3c.hu/forditasok/w3cfacts.html

14 World Wide Web Consortium. „Current Members”, hozzáférés: 2018. 10. 10, https://www.w3.org/Consortium/Member/List 


\section{NETWORKSHOP 2018}

Európai Kutatási Konzorcium az Informatikáért és Matematikáért'5, az Egyesült Államok-beli MIT Computer Science and Artificial Intelligence Laboratory ${ }^{16}$ és a japán Keio Egyetem7 koordinálja.

Az ajánlást 2012-ben minősítették szabványnak. A szabvány a ISO/IEC 40500:2012 ${ }^{18}$ kódszámot kapta.

\subsection{Az akadálymentesség három szintje}

A W3C szabványa az akadálymentességnek három szintjét határozza meg ${ }^{19}$ : $A$ szint (alapszint), $A A$ szint (emelt szint), AAA szint (legmagasabb szint).

$\mathrm{Az}$ alapszinten akadálymentes weboldalak úgy vannak kialakítva, hogy a legtöbb ember számára elháruljon minden olyan akadály, amely ellehetetleníti a weboldal tartalmának értelmezhetőségét. Ilyen megoldás lehet például, ha a webtartalom-fejlesztő a képeket úgynevezett helyettesítő szövegekkel látja el (alt attribútumok), hogy a felolvasóprogramok számára is értelmezhetővé váljon a kép tartalma. Gondoljunk csak arra, hogy milyen nehézséget jelent egy látássérült ember számára, ha egy weboldalon a menüpontok nevei nem szövegként, hanem egy-egy kép formájában jelennek meg.

Az emelt szintű akadálymentességet megvalósító weboldalak (AA szint) már nemcsak arra törekednek, hogy a legalapvetőbb akadályok is elháruljanak egy fogyatékossággal élő weboldalhasználó előtt, hanem úgy áll össze az oldal szerkezete és tartalma, hogy a böngészés ne csak lehetségessé váljon a képességeikben korlátozott weboldalhasználók számára, hanem kényelmes is legyen.

A legmagasabb szintű akadálymentességet elsősorban azokon a weboldalakon valósítják meg, amelyek kifejezetten a fogyatékkal élőknek szólnak, ám nem javasolják, hogy egy weboldal összes aloldala a AAA szint kritériumai szerint legyen felépítve, mivel vannak esetek, amikor rontja a felhasználói élményt, ha megpróbálunk megfelelni minden követelménynek.

\section{A Cselekvő közösségek wiki funkciói}

A portált úgy terveztük meg, hogy a Cselekvő közösségek projekt szakmai grémiuma által létrehozott lektorált tartalmak akkor is elérhetőek maradjanak eredeti formájukban, ha azokat a Cselekvő közösségek wiki felhasználói a jövőben továbbfejlesztik. Ezt úgy értük el, hogy minden általunk létrehozott szócikknek két változata érhető el az oldalról: a lektorált és a közösségi. A „Lektorált” menüpontban található az összes olyan szócikk, amelyeket a projekt munkatársai hoztak létre és töltöttek fel. Ezek

\footnotetext{
15 ERCIM. „Home”, hozzáférés: 2018. 10. 10, https://www.ercim.eu

16 MIT Computer Science \& Artificial Intelligence Lab. „About”, hozzáférés: 2018. 10. 10, https://www.csail.mit.edu/about

17 Keio University. „About Keio”, hozzáférés: 2018. 10.10, https://www.keio.ac.jp/en/about

18 International Organization for Standardization. „ISO/IEC 40500:2012”, hozzáférés: 2018. 10. 10, https://www.iso.org/standard/58625.html

19 World Wide Web Consortium. „Az 1. követelmény értelmezése”, hozzáférés: 2018. 10. 10, http://www.w3c.hu/forditasok/UNDERSTANDING-WCAG20/conformance.html\#uc-conf-req1-head
} 
nem szerkeszthetők bárki által, viszont minden itt lévő szócikknek van egy másolata a „Közösségi” kategóriában. A szócikkek e változata egy egyszerü regisztrációt követően bárki által szerkeszthető, illetve ide kerülnek azok a szócikkek is, amelyeket a Cselekvő közösségek wiki felhasználói hoztak létre. Ezek a szócikkek nem esnek át külön szakmai lektoráláson (csak egy előzetes moderáláson), a Wikipédiához hasonlóan mi is a közösségre bízzuk ezeknek a szócikkeknek a gondozását.

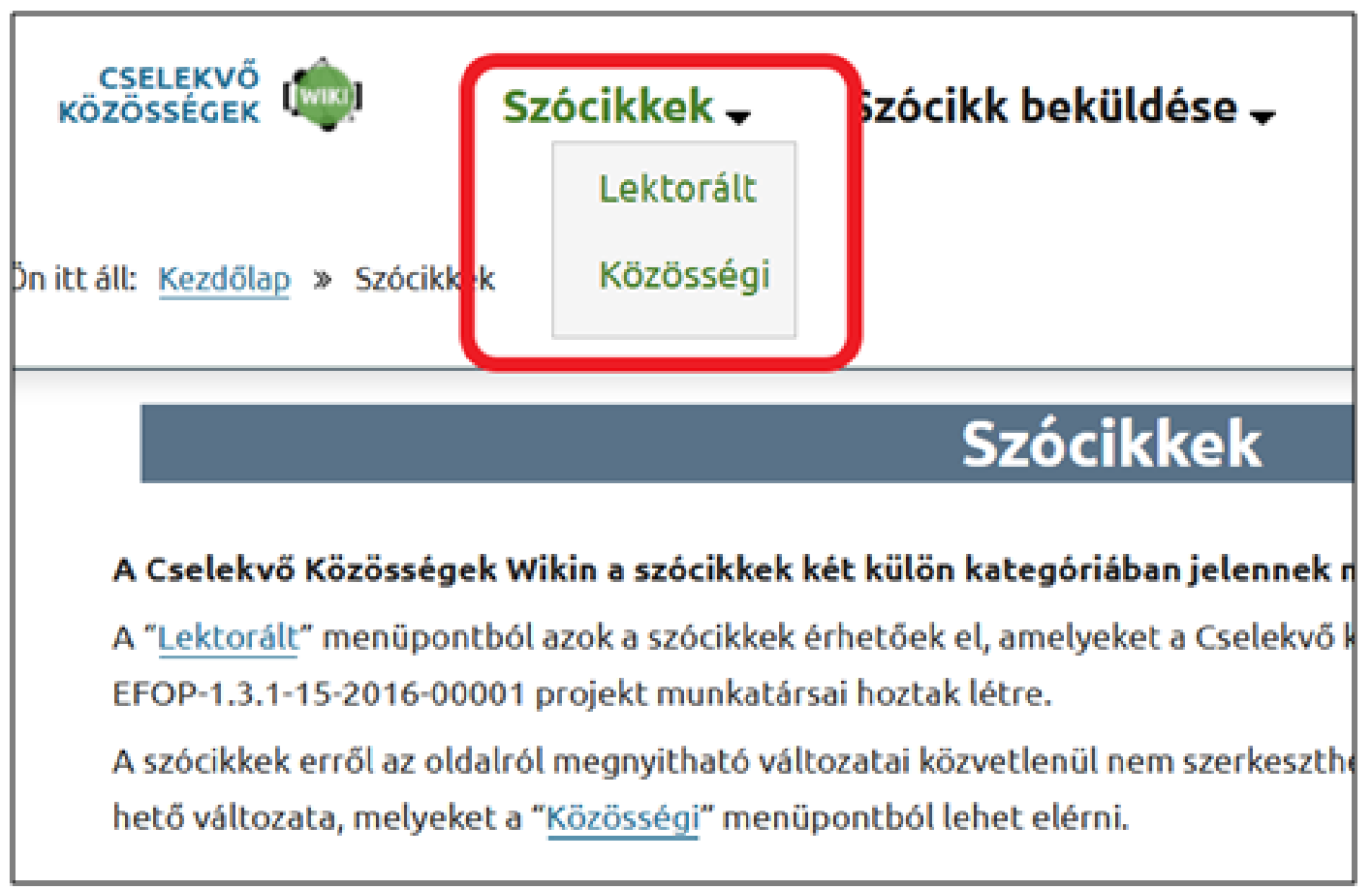

2. ábra a Szócikkek menüpontból lenyíló Lektorált és Közösségi almenüpont

A felületen elérhetővé tesszük és folyamatosan frissítjük azoknak a kiadványoknak a listáját, amelyek a projekt gondozásában jöttek létre.

Nemrég létrehoztuk az Év kérdése menüpontot is, ahol minden évben egy olyan aktuális és fontos kérdést teszünk fel a látogatóknak, amely aktív diskurzust igényel. A 2018-as év kérdése: „,Milyen lehetőségeket rejt az online tér a közösségek számára?"

2018 második felében elindult a wikiangol nyelvű felülete is, amelyet folyamatosan töltünkfel szócikkekkel.

\section{A Cselekvő közösségek wiki fejlesztésének tapasztalatai}

A fejlesztési projekt megvalósítása során WCAG 2.0 emelt szintü (AA) akadálymentességi kritériumainak igyekeztünk megfelelni, és ez végül sikerült is. A fejlesztés folyamatába akadálymentességi szakértőt vontunk be, aki fogyatékossággal élő személyek bevonásával alakította ki az oldal szerkezetét, tartalmi alapjait. A fejlesztés során a legnagyobb nehézséget az jelentette, hogy Európai Uniós projekt lévén nemcsak az akadálymentességi, hanem az Európai Unió projektjeiként létrejövő elektronikus felületekre vonatkozó kritériumoknak is meg kellett felelnünk, továbbá a Cselekvő közösségek - aktív közösségi 


\section{NETWORKSHOP 2018}

szerepvállalás EFOP-1.3.1-15 projekt belső Arculati Kézikönyvének szempontrendszerével is egyeztetnünk kellett a wiki arculatát.

Így tehát három teljesen eltérő kritériumrendszert kellett összhangba hoznunk. A Széchenyi 2020 Kedvezményezetti Arculati Kézikönyve ${ }^{20}$ elöírja, hogy a projektoldalakon el kell helyezni a Széchenyi 2020 logóját, a Magyar Kormány logóját, az Európai Unió zászlaját, a támogatási alap elnevezését és a „Befektetés a jövőbe” szlogent. Ezeken felül a projekt belső szabályzata alapján meg kellett jelenítenünk a konzorciumi partnerek logóját, továbbá a projekt saját logóját is. A felsorolt 10 kötelező tartalmi elemen felül a Cselekvő közösségek wiki saját tervezésü logóját is szerettük volna megjeleníteni a weboldalon. A Széchenyi 2020 Kedvezményezetti Arculati Kézikönyvének és a projekt belső arculati kézikönyvének a logók méretére és elhelyezésére vonatkozó utasításait még viszonylag egyszerü volt összehangolni, ám a WCAG 2.0 AA akadálymentességi szintjének már sokkal nehezebb volt megfelelni. Minden olyan elem, amely nem tartozik szervesen a weboldal tartalmához, rontja a weboldal használhatóságát és érthetőségét, továbbá, mivel az Európai Unió zászlajánál egyetlen logó sem lehet nagyobb a weboldalon belül, ezért két választása marad a fejlesztőnek: vagy az összes többi logó lesz nagyon apró (ami akadálymentességi szempontból aggályos), vagy az Európai Unió zászlaja foglal el egy jelentős részt a weboldal hasznos felületéből, ami szintén nem kedvez az akadálymentességnek.

Végül köztes megoldást választottunk és úgy terveztük át a Cselekvő közösségek wiki logóját, hogy az kis méretben is jól látható legyen.

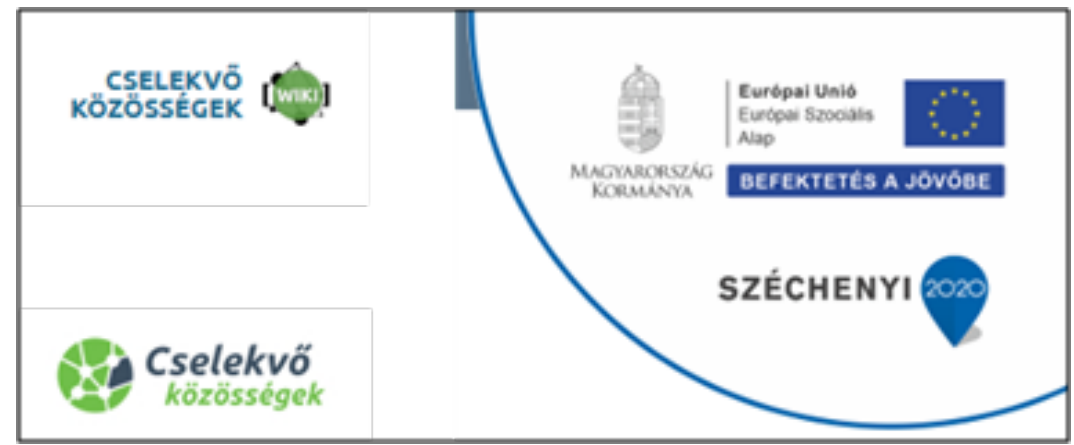

3. ábra a weboldalon elhelyezett három logó (montázs)

Ezcsakegypéldaaszámosleküzdendőproblémaközül,amelyekkelmindenkiszembesül,akiakadálymentes weboldal készítését tűzi ki céljául, ráadásul egy akadálymentes weboldal átadása még nem jelenti azt, hogy az oldal a jövőben is akadálymentes marad, az erről szóló tanúsítványt mindig egy konkrét időpontra állítják ki. Törekedni kell rá, hogy az akadálymentesség ne sérüljön, ehhez pedig ügyelni kell arra, hogy az oldalon elhelyezett tartalmak formázása is megfeleljen az akadálymentesség kritériumrendszerének. Egy módosítatlan WordPress tartalomkezelö rendszer ${ }^{21}$ grafikus szerkesztőfelülete nem alkalmas akadálymentes tartalmak előállítására, ugyanis ahhoz speciális formázásra van szükség, pl. a lábjegyzet elemeinek a <dt> HTML tag-ek közé kell kerülniük, az idézeteket pedig a <blockquote> vagy <q> HTML 
tag-ek közé kell helyezni (terjedelmüktől függően). A Cselekvő közösségek wikihez készítettem egy erről szóló részletes technikai útmutatót ${ }^{22}$ a tartalmat előállító felhasználók segítségére.

Az elhúzódó fejlesztés eredményeképp végül egy olyan weboldalt kaptunk, amely megfelel minden, a modern weboldalakkal szemben támasztott elvárásnak, ezen felül megvalósítja az emelt szintü akadálymentességet, és mind a projekt, mind az Európai Unió arculati kézikönyve kritériumainak is hiánytalanul eleget tesz.

\section{Oldalstatisztika és visszakereshetöség}

A Cselekvő közösségek wiki fejlesztésénél cél volt az, hogy tartalmi változásai nyomon követhetőek legyenek és a szócikkek egyes változatai a jövőben is elérhetőek maradjanak. Ezt úgy értük el, hogy a szócikkek szerkesztése során nem íródik felül a korábbi változat, hanem minden alkalommal egy új verzió készül, a régi változatok pedig bárki számára visszanézhetők. Ez a közismert Wikipédián is hasonlóan van megvalósítva, így nem veszik el senki szellemi terméke, és a közösség számára is lehetőséget biztosít a kontrollra a korábbi változatok visszanézhetősége révén.

A weboldalt ezen felül a webaratás módszerével is archiváljuk havonta egy alkalommal, ez azt jelenti, hogy egy automatizált szoftver segítségével havonta egyszer elmentjük a wiki összes oldalát egyszerü HTML formátumban. Az ,,aratást” az Internet Archive ${ }^{23}$ nonprofit vállalkozás szabadon elérhető Heritrix ${ }^{24}$ nevü szoftver segítségével valósítjuk meg.

A Cselekvő közösségek wikit 2018-ban havonta átlagosan 4111-en keresték fel, leglátogatottabb szócikke pedig a helyi cselekvési tervekről25 szól.

A wikit szívesen ajánlom nemcsupán a kulturális területen dolgozó szakembereknek, de mindenkinek, aki a magánéletében vagy a munkája során közösségekkel dolgozik együtt.

22 Cselekvő Közösségek Wiki. „Wiki szócikkek akadálymentesített formázása”, hozzáférés: 2018. 10. 10, https://cskwiki.hu/wiki-szocikkek-akadalymentesitett-formazasa

23 Internet Archive. „Föoldal”, hozzáférés: 2018. 10.10, https://archive.org

24 MIA wiki. „Heritrix”, hozzáférés: 2018.10. 10, http://mekosztaly.oszk.hu/mediawiki/index.php/Heritrix

25 Cselekvő Közösségek Wiki. „Helyi cselekvési terv”, hozzáférés: 2018. 10. 10, https://cskwiki.hu/helyi-cselekvesi-terv-2 